\title{
Prostaglandin moieties that determine receptor binding specificity in the bovine corpus luteum
}

\author{
L. E. Anderson ${ }^{1}$, M. K. Schultz ${ }^{2}$ and M. C. Wiltbank ${ }^{1 *}$ \\ ${ }^{1}$ Endocrinology-Reproductive Physiology Program and Department of Dairy Science, University of Wisconsin-Madison, 1675 \\ Observatory Drive, Madison, WI 53706 USA; and ' Department of Statistics, University of Wisconsin-Madison, Madison, WI 53706, USA
}

\begin{abstract}
This study provided a pharmacological evaluation of prostaglandin binding to bovine luteal plasma membrane. It was found that $\left[{ }^{3} \mathrm{H}\right] \mathrm{PGF}_{2 \alpha^{\prime}}\left[{ }^{3} \mathrm{H}\right] \mathrm{PGE}_{2^{\prime}}\left[{ }^{3} \mathrm{H}\right] \mathrm{PGE}_{1}$ and $\left[{ }^{3} \mathrm{H}\right] \mathrm{PGD}$, all bound with high affinity to luteal plasma membrane but had different specificities. Binding of $\left[{ }^{3} \mathrm{H}\right] \mathrm{PGF}_{2 \alpha}$ and $\left[{ }^{3} \mathrm{H}\right] \mathrm{PGD}_{2}$ was inhibited by non-radioactive $\mathrm{PGF}_{2 \alpha}\left(\mathrm{IC}_{50}\right.$ values of 21 and $9 \mathrm{nmol} \mathrm{l}^{-1}$, respectively), $\mathrm{PGD}_{2}$ (35 and $21 \mathrm{nmol} \mathrm{l}^{-1}$ ), and $\mathrm{PGE}_{2}\left(223\right.$ and $\left.81 \mathrm{nmol} \mathrm{l}^{-1}\right)$, but not by $\mathrm{PGE}_{1}\left(>10000\right.$ and $\left.5616 \mathrm{nmol} \mathrm{l}^{-1}\right)$. In contrast, $\left[{ }^{3} \mathrm{H}\right] \mathrm{PGE}_{1}$ was inhibited by non-radioactive $\mathrm{PGE}_{1}\left(14 \mathrm{nmol} \mathrm{l}^{-1}\right)$ and $\mathrm{PGE}_{2}\left(7 \mathrm{nmol} \mathrm{l}^{-1}\right)$, but minimally by $\mathrm{PGD}_{2}\left(2316 \mathrm{nmol} \mathrm{l}^{-1}\right)$ and $\mathrm{PGF}_{2 \alpha}\left(595 \mathrm{nmol} \mathrm{l}^{-1}\right)$. Binding of $\left[{ }^{3} \mathrm{H}\right] \mathrm{PGE}_{2}$ was inhibited by all four prostaglandins, but slopes of the dissociation curves indicated two binding sites. Binding of $\left[{ }^{3} \mathrm{H}\right] \mathrm{PGE}_{1}$ was inhibited, resulting in low $\mathrm{IC}_{50}$ values, by pharmacological agonists that are specific for $\mathrm{EP}_{3}$ receptor and possibly $\mathrm{EP}_{2}$ receptor. High affinity binding of $\left.{ }^{3} \mathrm{H}\right] \mathrm{PGF}_{2 \alpha}$ required a $\mathrm{C} 15$ hydroxyl group and a $\mathrm{C} 1$ carboxylic acid that are present on all physiological prostaglandins. Specificity of binding for the FP receptor depended on the C9 hydroxyl group and the C5/C6 double bond. Alteration of the $\mathrm{C} 11$ position had little effect on affinity for the FP receptor. In conclusion, there is a luteal EP receptor with high affinity for $\mathrm{PGE}_{1}, \mathrm{PGE}_{2}$, agonists of $\mathrm{EP}_{3}$ receptors, and some agonists of $\mathrm{EP}_{2}$ receptors. The luteal FP receptor binds $\mathrm{PGF}_{2 \alpha^{\prime}}$ $\mathrm{PGD}_{2}$ (high affinity), and $\mathrm{PGE}_{2}$ (moderate affinity) but not $\mathrm{PGE}_{1}$ due to affinity determination by the $\mathrm{C} 9$ and $\mathrm{C} 5 / \mathrm{C} 6$ moieties, but not the $\mathrm{C} 11$ moiety.
\end{abstract}

\section{Introduction}

Prostaglandins have a variety of regulatory functions in the corpus luteum. It is well established that $\mathrm{PGF}_{2 \alpha}$ is the primary initiator of luteolysis in many species, including all species of ruminant investigated (reviewed by Knickerbocker et al., 1988). The physiological role of type E prostaglandins is not clearly defined, but $\mathrm{PGE}_{2}$ or $\mathrm{PGE}_{1}$ have been implicated in regulation of the duration of the oestrous cycle, luteal progesterone production, luteolysis, and maternal recognition of pregnancy (Kimball and Lauderdale, 1975; Gimenez and Henricks, 1983).

Cloning studies show that prostaglandin receptors are members of the seven transmembrane domain receptor superfamily (reviewed by Negishi et al., 1995). Although prostaglandin receptors are similar in amino acid sequence and structure (Negishi et al., 1995) and prostaglandins are similar in chemical structure, it has been reported that prostaglandins only bind and activate specific receptors (Coleman et al., 1994). The current nomenclature for prostaglandin receptors corresponds to the naturally occurring prostanoid that binds to that receptor with the

*Correspondence.

Received 19 May 1998. highest affinity (for example $\mathrm{PGD}_{2}$ binds to the DP receptor, $\mathrm{PGF}_{2 \alpha}$ binds to the FP receptor; Coleman et al., 1995). There are multiple receptor subtypes that bind $\mathrm{PGE}_{2}\left(\mathrm{EP}_{1}, \mathrm{EP}_{2}\right.$, $\mathrm{EP}_{3^{\prime}}, \mathrm{EP}_{4} ;$ reviewed by Ushikubi et al., 1995) and specific pharmacological agonists have been used to differentiate EP receptor subtypes. Although a number of studies have evaluated prostaglandin binding in the corpus luteum of various species, no study has used specific pharmacological agonists to investigate the PGE receptor subtype in the corpus luteum. Accordingly, the first two experiments in this study were designed to characterize the specificity of prostaglandin binding and to identify the EP receptor subtypes in the bovine corpus luteum. Experiment 3 was designed to provide novel information on the precise moieties on the $\mathrm{PGF}_{2 \alpha}$ molecule that determine specificity of binding to the FP receptor.

\section{Materials and Methods}

\section{Reagents}

Misoprostol and SC-19220 were gifts from G. D. Searle (Skokie, IL). Sulprostone and M\&B 28,767 were donated by Schering (Berlin) and Rhône-Poulenc Rorer Ltd (Dagenham), 
respectively. All other non-radioactive prostaglandins and prostaglandin derivatives were obtained from Cayman Chemical (Ann Arbor, MI). [ $\left.{ }^{3} \mathrm{H}\right] \mathrm{PGD}_{2},\left[{ }^{3} \mathrm{H}\right] \mathrm{PGE}_{1},\left[{ }^{3} \mathrm{H}\right] \mathrm{PGE}_{2}$, and $\left[{ }^{3} \mathrm{H}\right] \mathrm{PGF}_{2 \alpha}$ were purchased from New England Nuclear/Dupont (Boston, MA). Gelatin was purchased from Difco Laboratories (Detroit, MI). All other chemicals were obtained from Sigma Chemical Company (St Louis, MO).

\section{Tissue homogenization}

Mid-cycle corpora lutea were selected from bovine ovaries obtained from an abattoir. Minced corpora lutea were suspended in tissue homogenization buffer $(10 \mathrm{mmol}$ trizma hydrochloride $1^{-1}, 20 \mathrm{mmol}$ sucrose $1^{-1}, 1 \mathrm{mmol} \mathrm{CaCl}_{2} \mathrm{I}^{-1}$, $1 \mathrm{mmol} \mathrm{MgCl}_{2} \mathrm{l}^{-1}, 0.02 \%$ (w/v) $\mathrm{NaN}_{3}, \mathrm{pH} 7.0$ ). Tissue was homogenized on ice using an ultraturrax homogenizer (Tekmar Company, Cincinnati, $\mathrm{OH}$ ) initially and then with a Wheaton glass tissue grinder (Fisher Scientific, Pittsburgh, PA). The plasma membrane fraction was obtained by centrifuging the homogenized tissues three times at $3000 \mathrm{~g}$ for $5 \mathrm{~min}$ at $4^{\circ} \mathrm{C}$ to remove tissue debris. The supernatant was then centrifuged at $30000 \mathrm{~g}$ for $30 \mathrm{~min}$ at $4^{\circ} \mathrm{C}$. The plasma membrane pellet was resuspended in tissue homogenization buffer. Protein content was measured using the Bio-Rad protein assay (Bio-Rad Laboratories, Hercules, CA). Aliquots were stored at $-70^{\circ} \mathrm{C}$. Immediately before receptor binding studies, the tissue was thawed on ice and then centrifuged for $30 \mathrm{~min}$ at $30000 \mathrm{~g}$. The pellet was resuspended in assay buffer (20 $\mathrm{mmol} 2-[\mathrm{N}$-morpholino]ethanesulfonic acid (MES) $1^{-1}, 10 \mathrm{mmol} \mathrm{CaCl}_{2} \mathrm{l}^{-1}, 10 \mathrm{mmol}$ $\mathrm{MgCl}_{2} \mathrm{I}^{-1}, 0.02 \%(\mathrm{w} / \mathrm{v}) \mathrm{NaN}_{3}, 0.1 \%(\mathrm{w} / \mathrm{v})$ gelatin, $\left.\mathrm{pH} 6.0\right)$. A single luteal plasma membrane preparation was used for Expts 1 and 2 and a different preparation was used for Expt 3 .

\section{Radioreceptor assays}

A time and temperature course of the binding assay described below was run initially to determine a single time point and temperature at which $\left[{ }^{3} \mathrm{H}\right] \mathrm{PGD}_{2},\left[{ }^{3} \mathrm{H}\right] \mathrm{PGE}_{1}$, $\left[{ }^{3} \mathrm{H}\right] \mathrm{PGE}_{2}$ and $\left[{ }^{3} \mathrm{H}\right] \mathrm{PGF}_{2 \alpha}$ showed stable binding. Three incubation temperatures $\left(4^{\circ} \mathrm{C}, 20^{\circ} \mathrm{C}\right.$, and $\left.37^{\circ} \mathrm{C}\right)$ and seven time points $(0.5,1,2,4,8,12$ and $24 \mathrm{~h})$ were examined. Binding was stable for all four $\left[{ }^{3} \mathrm{H}\right]$ prostaglandins at $4^{\circ} \mathrm{C}$ between 12 and 24 h. All other radioreceptor assays were run at $4^{\circ} \mathrm{C}$ for $20 \mathrm{~h}$.

Assays were conducted in low-binding 96-well microtitre plates (Fisher Scientific, Pittsburgh, PA) in $100 \mu$ l volume using $200 \mu \mathrm{g}$ plasma membrane protein. Tritiated prostaglandins ( $3 \mathrm{nmol} \mathrm{I}^{-1}$ ) were inhibited by various concentrations of non-radioactive prostaglandins or prostaglandin agonists (1-10000 $\mathrm{nmol} \mathrm{l}^{-1}$ ) diluted in assay buffer. Samples were incubated on a microtitre plate shaker (Fisher Scientific, Pittsburgh, PA) for $20 \mathrm{~h}$ at $4^{\circ} \mathrm{C}$. Free prostaglandins were separated from bound prostaglandins by rapid filtration with a cell harvester. Plasma membrane protein (containing bound prostaglandin) was collected on glass fibre filter paper (Schleicher \& Schuell Inc., Keene, NH) and washed thoroughly with wash buffer $\left(20 \mathrm{mmol} \mathrm{MES} \mathrm{I}^{-1}, 1 \mathrm{mmol}\right.$ $\left.\mathrm{CaCl}_{2} \mathrm{l}^{-1}, 1 \mathrm{mmol} \mathrm{MgCl} \mathrm{l}^{-1}, 0.02 \%(\mathrm{w} / \mathrm{v}) \mathrm{NaN}_{3^{\prime}} \mathrm{pH} 6.0\right)$ at $4^{\circ} \mathrm{C}$.
Samples were placed in BioSafe II scintillation fluid (Beckman Co., Fullerton, CA), vortexed for $1 \mathrm{~min}$, and stored in a dark area for at least $12 \mathrm{~h}$. Samples were placed in a scintillation counter for $3 \mathrm{~min}$ to determine the amount of radioactivity. Inhibition curves were constructed for each radioactive and each non-radioactive prostaglandin.

Scatchard analysis was used to determine the number and affinity of FP and EP receptors by displacement of $\left[{ }^{3} \mathrm{H}\right] \mathrm{PGE}_{1}$ and $\left[{ }^{3} \mathrm{H}\right] \mathrm{PGF}_{2 \alpha}$ by non-radioactive $\mathrm{PGE}_{1}$ and $\mathrm{PGF}_{2 \alpha^{\prime}}$ respectively (Scatchard, 1949). The procedures were similar to those for the inhibition curve assays. The assays were conducted in 96-well microtitre plates in $100 \mu$ l using 106.5 and $213.0 \mu \mathrm{g}$ plasma membrane protein (15 and $30 \mathrm{mg}$ initial weight of corpora lutea, respectively). $\left[{ }^{3} \mathrm{H}\right] \mathrm{PGE}_{1}$ and ${ }^{3} \mathrm{H}_{\mathrm{PGF}}\left(3 \mathrm{nmol} \mathrm{1}^{-1}\right)$ binding was inhibited by increasing amounts $\left(0.06-6 \mathrm{nmol} \mathrm{l}^{-1}\right)$ of cold $\mathrm{PGE}_{1}$ and $\mathrm{PGF}_{2 \alpha^{\prime}}$ respectively.

Non-radioactive $\mathrm{PGD}_{2}, \mathrm{PGE}_{1}, \mathrm{PGE}_{2}$, or $\mathrm{PGF}_{2 \alpha}\left(10 \mu \mathrm{mol} \mathrm{l} \mathrm{l}^{-1}\right.$ approximately equivalent to $3.5 \mu \mathrm{g}$ prostaglandin $\mathrm{ml}^{-1}$ ) was incubated for $20 \mathrm{~h}\left(4^{\circ} \mathrm{C}\right)$ with bovine luteal plasma membrane in conditions similar to those for the radioreceptor assay to test for degradation of $\mathrm{PGF}_{2 \alpha}$ or conversion of prostaglandins to $\mathrm{PGF}_{2 \alpha^{\prime}}$. Plasma membrane was removed by centrifugation at $30000 \mathrm{~g}$ for $30 \mathrm{~min}$ at $4^{\circ} \mathrm{C}$, and the assay buffer from each sample was analysed for $\mathrm{PGF}_{2 \alpha}$ by radioimmunoassay (Townson and Pate, 1994).

\section{Statistical analysis}

The data from the inhibition curves in Expt 1 were applied to a logistic model to estimate the concentration at which $50 \%$ binding occurred and the slope of the curve at that point. The non-linear regression routine in S-plus software (Mathsoft Inc., Seattle, WA) was used. The model assumes that the response will start at $100 \%$ for low concentrations of non-radioactive prostaglandins and decrease toward $0 \%$ as the concentration of non-radioactive prostaglandin increases. The following form of the model was used:

$$
p=1-\left\{1 /\left[1+\exp \left(\left(x-\theta_{1}\right) / \theta_{2}\right)\right]\right\}
$$

where $x=\log _{10}$ (concentration of non-radioactive prostaglandin) and $p=$ percentage $\left[{ }^{3} \mathrm{H}\right]$ prostaglandin bound $/ 100$. With this parameterization, $\theta_{1}$ is the $x$ value on the $\log$ scale where the curve reaches half its height ( $p=0.5$ or the $\mathrm{IC}_{50}$ value), and $\theta_{2}$ is a scale parameter, measured in the units of the $x$-axis, and is related to the steepness of the curve. The derivative of the curve (slope) at $50 \%$ is $1 /\left(4 \times \theta_{2}\right)$. The absolute value of $\theta_{2}$ is the distance on the $x$-axis over which the response decreases from 73.1 to $50 \%$, and from 50 to $26.9 \%$, due to the symmetry of the curve. This parameter is inversely related to the slope of the curve; a large $\theta_{2}$ reflects a relatively flat curve, whereas a small $\theta_{2}$ corresponds to a steep rapidly descending curve. Within each curve, the variability appeared homogeneous. Among the curves there were differences in variability as reflected in the widths of the confidence intervals for the parameter estimates. Nominal $95 \%$ confidence intervals for $\theta_{1}$ and $\theta_{2}$ were computed using each parameter estimate and its standard error (Tables 1 and 2) to facilitate comparisons across multiple curves. 
Table 1. Inhibition (50\%) of radioactive prostaglandins by non-radioactive prostaglandins bound to bovine luteal plasma membrane

\begin{tabular}{|c|c|c|c|c|}
\hline Radioactive prostaglandin & $\mathrm{PGD}_{2}$ & $\mathrm{PGE}_{1}$ & $\mathrm{PGE}_{2}$ & $\mathrm{PGF}_{2 \alpha}$ \\
\hline$\left[{ }^{3} \mathrm{H}\right] \mathrm{PGD}{ }_{2}$ & $\begin{array}{c}21 \\
(18,24)\end{array}$ & $\begin{array}{c}5616 \\
(4799,6572)\end{array}$ & $\begin{array}{c}81 \\
(68,97)\end{array}$ & $\begin{array}{c}9 \\
(8,11)\end{array}$ \\
\hline$\left[{ }^{3} \mathrm{H}\right] \mathrm{PGE}_{1}$ & $\begin{array}{c}2316 \\
(1703,3148)\end{array}$ & $\begin{array}{c}14 \\
(11,17)\end{array}$ & $\begin{array}{c}7 \\
(6,9)\end{array}$ & $\begin{array}{c}595 \\
(453,782)\end{array}$ \\
\hline$\left[{ }^{3} \mathrm{H}\right] \mathrm{PGE}_{2}$ & $\begin{array}{c}242 \\
(172,339)\end{array}$ & $\begin{array}{c}81 \\
(58,112)\end{array}$ & $\begin{array}{c}9 \\
(7,12)\end{array}$ & $\begin{array}{c}66 \\
(49,88)\end{array}$ \\
\hline$\left[{ }^{3} \mathrm{H}\right] \mathrm{PGF}_{2 \alpha}$ & $\begin{array}{c}35 \\
(27,45)\end{array}$ & $>10000$ & $\begin{array}{c}223 \\
(176,282)\end{array}$ & $\begin{array}{c}21 \\
(17,26)\end{array}$ \\
\hline
\end{tabular}

$n=3$ experiments performed in triplicate. $\mathrm{IC}_{50}\left(\mathrm{nmol} \mathrm{l}^{-1}\right)=$ mean. Confidence intervals $(95 \%)$ are shown in parentheses (lower limit, upper limit). For calculation of $\theta_{1}$ and standard errors the data were in $\log$ units. Values were transformed to the inverse log of $\theta_{1}$ to provide $\mathrm{IC}_{50}$ values, thus the confidence intervals appear asymmetrical.

Table 2. Scale parameter $\left(\theta_{2}=\right.$ distance on $x$-axis from 73.1 to $50 \%$ bound) for displacement by non-radioactive prostaglandins of radioactive prostaglandins bound to bovine luteal plasma membrane*

\begin{tabular}{|c|c|c|c|c|c|}
\hline Radioactive prostaglandin & $\mathrm{PGD}_{2}$ & $\mathrm{PGE}_{1}$ & $\mathrm{PGE}_{2}$ & $\mathrm{PGF}_{2 \alpha}$ & Row average \\
\hline$\left[{ }^{3} \mathrm{H}\right] \mathrm{PGD}_{2}$ & $\begin{array}{l}0.48 \\
(0.42,0.54)\end{array}$ & $\begin{array}{l}0.46 \\
(0.39,0.53)\end{array}$ & $\begin{array}{l}0.60 \\
(0.53,0.66)\end{array}$ & $\begin{array}{l}0.50 \\
(0.44,0.56)\end{array}$ & 0.51 \\
\hline$\left[{ }^{3} \mathrm{H}\right] \mathrm{PGE}_{1}$ & $\begin{array}{l}0.74 \\
(0.60,0.88)\end{array}$ & $\begin{array}{l}0.43 \\
(0.33,0.52)\end{array}$ & $\begin{array}{l}0.49 \\
(0.39,0.58)\end{array}$ & $\begin{array}{l}0.65 \\
(0.54,0.75)\end{array}$ & 0.57 \\
\hline$\left[{ }^{3} \mathrm{H}\right] \mathrm{PGE}_{2}$ & $\begin{array}{l}0.99 \\
(0.85,1.13)\end{array}$ & $\begin{array}{l}0.92 \\
(0.79,1.06)\end{array}$ & $\begin{array}{l}0.60 \\
(0.50,0.70)\end{array}$ & $\begin{array}{l}0.76 \\
(0.65,0.88)\end{array}$ & 0.82 \\
\hline$\left[{ }^{3} \mathrm{H}\right] P G F_{2 \alpha}$ & $\begin{array}{l}0.53 \\
(0.44,0.62)\end{array}$ & $\begin{array}{l}0.36 \\
(0.19,0.53)\end{array}$ & $\begin{array}{l}0.46 \\
(0.38,0.55)\end{array}$ & $\begin{array}{l}0.37 \\
(0.30,0.45)\end{array}$ & 0.43 \\
\hline
\end{tabular}

*The curve is symmetrical so the scale parameter describes the slope between 26.9 and $73.1 \%$. The estimated slope of the curve at $50 \%$ is $1 /\left(4 \times \theta_{2}\right)$.

$n=3$ experiments performed in triplicate. Values are predicted scale parameters from logistic model fit. Confidence intervals $(95 \%)$ are shown in parentheses (lower limit, upper limit).

\section{Results}

\section{Time and temperature effects on binding}

All four tritiated prostaglandins demonstrated stable binding at $4^{\circ} \mathrm{C}$ between 12 and $24 \mathrm{~h}$. This was not necessarily the highest point of binding for each individual prostaglandin. However, under these conditions, all $\left[{ }^{3} \mathrm{H}\right]$ prostaglandins bound with high affinity to bovine luteal plasma membrane.

\section{Experiment 1: prostaglandin receptors in the corpus luteum}

The number of $\left[{ }^{3} \mathrm{H}\right] \mathrm{PGF}_{2 \alpha}$ molecules specifically bound to $200 \mu \mathrm{g}$ plasma membrane protein was $6.7 \pm 0.5 \times 10^{10}$ (mean \pm SEM). Binding of $\left[{ }^{3} \mathrm{H}\right] \mathrm{PGF}_{2 \alpha}$ (Fig. 1a, Table 1) was inhibited by non-radioactive $\mathrm{PGF}_{2 \alpha}$ and $\mathrm{PGD}_{2}$ with similar affinity $\left(\mathrm{IC}_{50}=21\right.$ and $35 \mathrm{nmol} \mathrm{l}^{-1}$, respectively). Cold $\mathrm{PGE}_{2}$ displaced $\left[{ }^{3} \mathrm{H}\right] \mathrm{PGF}_{2 \alpha}$ binding with lower affinity $\left(\mathrm{IC}_{50}=223 \mathrm{nmol} \mathrm{l}^{-1}\right)$, whereas $\mathrm{PGE}_{1}$ did not inhibit the binding of $\left[{ }^{3} \mathrm{H}\right] \mathrm{PGF}_{2 \alpha}$ to luteal plasma membrane $\left(\mathrm{IC}_{50}>10 \mu \mathrm{mol} \mathrm{l}^{-1}\right)$.

The number of $\left[{ }^{3} \mathrm{H}\right] \mathrm{PGD}_{2}$ molecules specifically bound to $200 \mu \mathrm{g}$ plasma membrane protein was $4.6 \pm 0.6 \times 10^{10}$ (mean $\pm \mathrm{SEM})$. Similar to $\left[{ }^{3} \mathrm{H}\right] \mathrm{PGF}_{2 \alpha}$ binding, $\left[{ }^{3} \mathrm{H}\right] \mathrm{PGD}_{2}$ binding
(Fig. 1b, Table 1) was inhibited by $\mathrm{PGD}_{2}\left(\mathrm{IC}_{50}=21 \mathrm{nmol} \mathrm{l}^{-1}\right)$, $\mathrm{PGF}_{2 \alpha}\left(\mathrm{IC}_{50}=9 \mathrm{nmol} \mathrm{l}^{-1}\right)$ and PGE ${ }_{2}\left(\mathrm{IC}_{50}=81 \mathrm{nmol} \mathrm{l}^{-1}\right)$. Nonradioactive $\mathrm{PGE}_{1}$ only displaced $\left[{ }^{3} \mathrm{H}\right] \mathrm{PGD}_{2}$ at a high concentration $\left(\mathrm{IC}_{50}=5616 \mathrm{nmol} \mathrm{l}^{-1}\right)$. The number of $\left[{ }^{3} \mathrm{H}\right] \mathrm{PGE}_{1}$ molecules specifically bound to $200 \mathrm{\mu g}$ plasma membrane protein was $1.6 \pm 0.1 \times 10^{10}$ (mean $\pm \mathrm{SEM}$ ). Both $\mathrm{PGE}_{1}$ and $\mathrm{PGE}_{2}$ displaced the binding of $\left[{ }^{3} \mathrm{H}\right] \mathrm{PGE}_{3}$ to luteal plasma membrane with similar affinity $\left(\mathrm{IC}_{50}=14\right.$ and $7 \mathrm{nmol} \mathrm{l}^{-1}$, respectively). At much higher concentrations, $\mathrm{PGF}_{2 \alpha}\left(\mathrm{IC}_{50}=\right.$ $\left.595 \mathrm{nmol} \mathrm{l}^{-1}\right)$ and $\mathrm{PGD}_{2}\left(\mathrm{IC}_{50}=2316 \mathrm{nmol} \mathrm{l}^{-1}\right)$ inhibited $\left[{ }^{3} \mathrm{H}\right] \mathrm{PGE}_{1}$ binding (Table 1, Fig. 1c).

The number of $\left[{ }^{3} \mathrm{H}\right] \mathrm{PGE}_{2}$ molecules specifically bound to $200 \mu$ g plasma membrane protein was $2.9 \pm 0.2 \times 10^{10}$ (mean \pm SEM). Binding of $\left[{ }^{3} \mathrm{H}_{3} \mathrm{PGE}_{2}\right.$ was inhibited with a low concentration of $\mathrm{PGE}_{2}\left(\mathrm{IC}_{50}=9 \mathrm{nmol} \mathrm{l}^{-1}\right)$. Higher concentrations of $\mathrm{PGF}_{2 \alpha}\left(\mathrm{IC}_{50}=66 \mathrm{nmol} \mathrm{l}^{-1}\right), \mathrm{PGE}_{1}\left(\mathrm{IC}_{50}=81 \mathrm{nmol} \mathrm{l}^{-1}\right)$ and $\mathrm{PGD}_{2}\left(\mathrm{IC}_{50}=242 \mathrm{nmol} \mathrm{l}^{-1}\right)$ were required to displace $\left[{ }^{3} \mathrm{H}_{\mathrm{PGE}}\right.$ (Fig. 1d, Table 1).

The scale parameters relate to the slope between $27 \%$ and $73 \%$ (Table 2) and were greatest for displacement of $\left[{ }^{3} \mathrm{H}\right] \mathrm{PGE}_{2}$. This is consistent with the relatively flat displacement lines for $\left[{ }^{3} \mathrm{H}\right] \mathrm{PGE}_{2}$ (Fig. 1d). Two other scale parameters that were relatively large were for the displacement of $\left[{ }^{3} \mathrm{H}\right] \mathrm{PGE}_{1}$ by $\mathrm{PGD}_{2}$ and $\mathrm{PGF}_{2 \alpha}$. The remaining scale parameters were between 0.36 and 0.60 . From these results, the decision was 

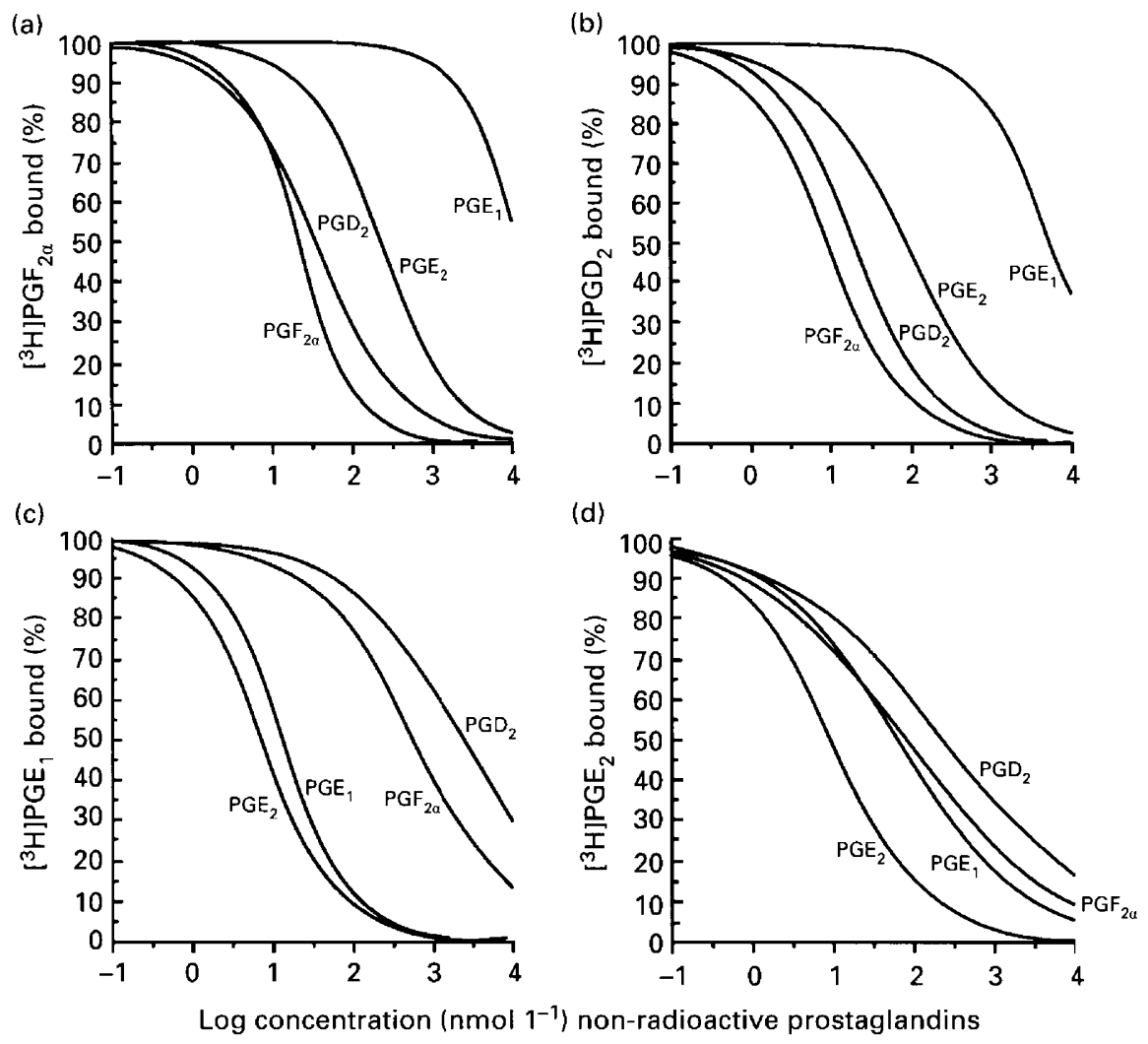

Fig. 1. Inhibition of (a) $\left[{ }^{3} \mathrm{H}\right] \mathrm{PGF}_{2 \alpha^{\prime}}$ (b) $\left[{ }^{3} \mathrm{H}\right] \mathrm{PGD}_{2^{\prime}}$ (c) $\left[{ }^{3} \mathrm{H}\right] \mathrm{PGE}_{1}$ and (d) $\left[{ }^{3} \mathrm{H}\right] P G E_{2}$ by various non-radioactive prostaglandins in bovine luteal plasma membrane. $n=3$ experiments in triplicate.

made to use $\left[{ }^{3} \mathrm{H}\right] P \mathrm{PE}_{1}$ to characterize further the EP receptors, since the $\left[{ }^{3} \mathrm{H}\right] \mathrm{PGE}_{2}$ binding results were compromised by the apparent binding of $\mathrm{PGE}_{2}$ to both $\mathrm{EP}$ and $\mathrm{FP}$ receptors.

The radioimmunoassay did not detect an increase in the concentration of $\mathrm{PGF}_{2 \alpha}$ in the assay buffer after $20 \mathrm{~h}$ incubation of high concentrations of non-radioactive $\mathrm{PGD}_{2}$, $\mathrm{PGE}_{1}, \mathrm{PGE}_{2}$ or $\mathrm{PGF}_{2 \alpha}$ with bovine luteal plasma membrane, indicating that $\mathrm{PGD}_{2}, \mathrm{PGE}_{1}$ and $\mathrm{PGE}_{2}$ were not being converted to $\mathrm{PGF}_{2 \alpha}$ (data not shown). There appeared to be some crossreactivity of $\mathrm{PGD}_{2}$ and $\mathrm{PGE}_{2}$ with the $\mathrm{PGF}_{2 \alpha}$ antibody, since a value of $0.1-1.0 \mathrm{ng} \mathrm{PGF}_{2 \alpha} \mathrm{ml}^{-1}$ was detected for $\mathrm{PGD}_{2}$ and $\mathrm{PGE}_{2}$ before incubation with plasma membrane. The $\mathrm{PGF}_{2 \alpha}$ concentration detected in the assay buffer before and after $20 \mathrm{~h}$ incubation of $\mathrm{PGD}_{2}$ or $\mathrm{PGE}_{2}$ with bovine luteal plasma membrane decreased by $60 \%$ and $97 \%$, respectively, indicating possible prostaglandin degradation.

Scatchard analysis showed a single high affinity binding site for $\left[{ }^{3} \mathrm{H}\right] \mathrm{PGE}_{1}$ and $\left[{ }^{3} \mathrm{H}\right] \mathrm{PGF}_{2 \alpha}$ (Fig. 2). The dissociation constants $\left(K_{d}\right)$ for the EP receptor were 7.6 and $9.2 \mathrm{nmol} \mathrm{1}^{-1}$ for 106.7 and $213.0 \mu \mathrm{g}$ luteal plasma membrane protein, respectively (equivalent to 15 and $30 \mathrm{mg}$ of initial corpus luteum). The concentration of EP receptors $\left(B_{\max }\right)$ was 437 and $507 \mathrm{amol}_{\mathrm{g}} \mathrm{g}^{-1}$ protein for 213.0 and $106.7 \mu \mathrm{g}$ plasma membrane protein, respectively (Fig. 2). The dissociation constant for the FP receptor was $11.4 \mathrm{nmol} \mathrm{l}^{-1}$ for $216 \mu \mathrm{g}$ plasma membrane protein and $11.1 \mathrm{nmol} \mathrm{l}^{-1}$ for $106.7 \mu \mathrm{g}$ plasma membrane protein. The concentration of FP receptors in the plasma membrane was 2915 and $2986{\mathrm{amol} \mu \mathrm{g}^{-1}}^{-1}$ protein for 213.0 and $106.5 \mu \mathrm{g}$ plasma membrane protein, respectively (Fig. 2).

\section{Experiment 2: EP receptor subtype determination}

A variety of relatively specific agonists was used to inhibit $\left[{ }^{3} \mathrm{H}\right] \mathrm{PGE}_{1}$ binding to determine the EP receptor subtype in the bovine corpus luteum. $\mathrm{M} \& \mathrm{~B} 28,767 \quad\left(\mathrm{EP}_{3}\right.$ receptor agonist), 11-deoxy $\mathrm{PGE}_{1}\left(\mathrm{EP}_{2}>\mathrm{EP}_{3}\right)$, 16,16-dimethyl $\mathrm{PGE}_{2}$ $\left(\mathrm{EP}_{3}>\mathrm{EP}_{1}>\mathrm{EP}_{2}\right), 17$-phenyl trinor $\mathrm{PGE}_{2}\left(\mathrm{EP}_{1}>\mathrm{EP}_{3}\right)$, and sulprostone $\left(\mathrm{EP}_{3}>\mathrm{EP}_{1}\right)$ displaced $\left[{ }^{3} \mathrm{H}\right] \mathrm{PGE}_{1}$ binding with relatively high affinity $\left(\mathrm{IC}_{50}=3,8,9,17\right.$ and $23 \mathrm{nmol} \mathrm{l}^{-1}$, respectively) (Table 3 ). Misoprostol $\left(\mathrm{EP}_{2}>\mathrm{EP}_{3}\right)$ inhibited $\left[{ }^{3} \mathrm{H}\right] \mathrm{PGE}$ binding at a higher concentration $\left(\mathrm{IC}_{50}=82 \mathrm{nmol}\right.$ $\left.\mathrm{l}^{-1}\right)$, whereas SC-19220 (EP $)$ did not displace $\left[{ }^{3} \mathrm{H}\right] \mathrm{PGE}_{1}$ binding $\left(\mathrm{IC}_{50}>10000 \mathrm{nmol} \mathrm{l}^{-1}\right.$ ) (Table 3). Similar to $\mathrm{PGF}_{2 \alpha^{\prime}}$ fluprostenol (FP receptor agonist) was not able to inhibit $\left.{ }^{3} \mathrm{H}\right] \mathrm{PGE}$ binding effectively $\left(\mathrm{IC}_{50}=6167 \mathrm{nmol} \mathrm{l}^{-1}\right)$.

\section{Experiment 3: determination of essential sites for $P G F_{2 a}$ binding to FP receptor}

Alterations to $\mathrm{C} 1$ of $\mathrm{PGF}_{2 \alpha}$ markedly decreased the ability of prostaglandin derivatives to inhibit $\left[{ }^{3} \mathrm{H}\right] \mathrm{PGF}_{2 \alpha}$ binding. The $\mathrm{IC}_{50}$ value for $\mathrm{PGF}_{2 \alpha}$ dimethyl amide was $>10 \mu \mathrm{mol} \mathrm{l} \mathrm{l}^{-1}$ and for $\mathrm{PGF}_{2 \alpha}$ isopropyl ester was $383 \pm 27 \mathrm{nmol}^{-1}$ (Table 4). 
(a)

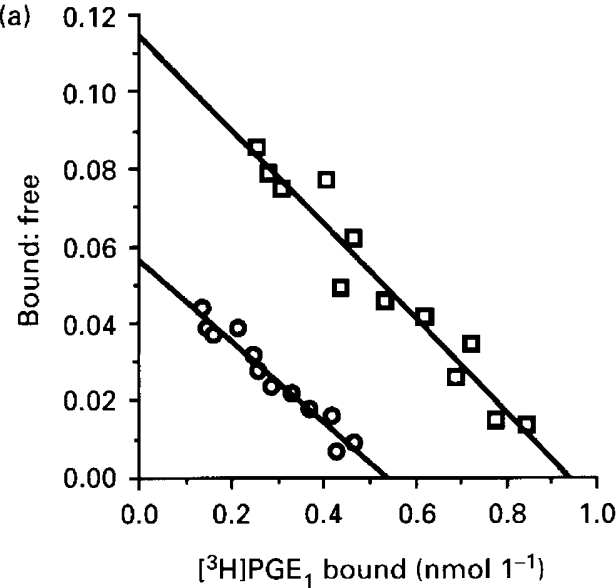

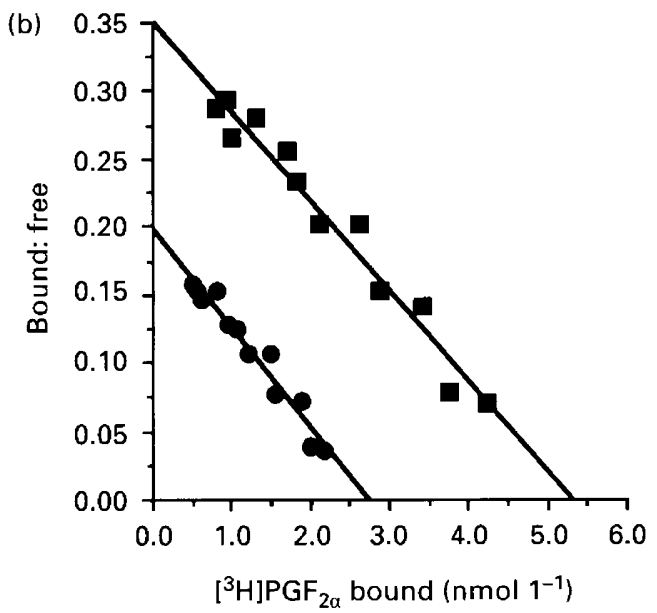

Fig. 2. Scatchard plot of the binding of $(\mathrm{a})\left[{ }^{3} \mathrm{H}\right] \mathrm{PGE}_{1}\left(213 \mu \mathrm{g}\right.$ luteal plasma membrane protein: $K_{d}=7.6 \pm$ $0.3 \mathrm{nmol} 1^{-1} ; B_{\max }=437 \pm 14 \mathrm{amol}_{\mu g^{-1}}$ plasma membrane protein; $106.7 \mu \mathrm{g}$ luteal plasma membrane protein: $K_{d}=9.2 \pm 0.3 \mathrm{nmol} \mathrm{l^{-1 }} ; B_{\max }=507 \pm 28$ amol $\mathrm{ug}^{-1}$ plasma membrane protein) and (b) $\left[{ }^{3} \mathrm{H}\right] \mathrm{PGF}_{2 \alpha}$

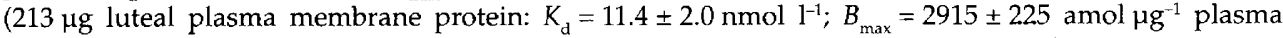
membrane protein; $106.7 \mu \mathrm{g}$ luteal plasma membrane protein: $K_{\mathrm{d}}=11.1 \pm 1.5 \mathrm{nmol} \mathrm{l}^{-1} ; B_{\max }=2986 \pm 225$ amol $\mu \mathrm{g}^{-1}$ plasma membrane protein) to a pool of bovine luteal plasma membrane. $(\square, \boldsymbol{m}) 213 \mu \mathrm{g}$ luteal plasma membrane protein; $(0, \bullet) 106.7 \mu \mathrm{g}$ luteal plasma membrane protein.

Similarly, oxidation at C15 (15-keto $\mathrm{PGF}_{2 \alpha}$ ) substantially altered binding of $\left[{ }^{3} \mathrm{H}\right] \mathrm{PGF}_{2 \alpha} \quad\left(\mathrm{IC}_{50}=667 \pm 145 \mathrm{nmol} \mathrm{l}^{-1}\right)$ (Table 4).

Reduction at $\mathrm{C} 9\left(\mathrm{PGE}_{2}\right)$ had a moderate effect on $\left[{ }^{3} \mathrm{H}\right] \mathrm{PGF}{ }_{2 \alpha}$ binding $\left(\mathrm{IC}_{50}=157 \pm 27 \mathrm{nmol} \mathrm{l}^{-1}\right)$. Similarly, changes at the double bond between $\mathrm{C} 5$ and $\mathrm{C} 6$ decreased inhibition of $\left[{ }^{3} \mathrm{H}\right] \mathrm{PGF}_{2 \alpha}$ binding (5-trans $\mathrm{PGF}_{2 \alpha^{\prime}} \mathrm{PGF}_{1 \alpha^{\prime}} \mathrm{IC}_{50}=$ $61 \pm 5,153 \pm 22$, respectively; Table 4 )

Changes at other sites in $\mathrm{PGF}_{2 \alpha}$ had a minimal effect on inhibition of [ $\left.{ }^{3} \mathrm{H}\right] \mathrm{PGF}_{2 \alpha}$ binding. $\mathrm{PGD}_{2}$ and 11-deoxy $\mathrm{PGF}_{2 \alpha}$ (changes at $\mathrm{C} 11$ ) had $\mathrm{IC}_{50}$ values of $27 \pm 3$ and $37 \pm 4 \mathrm{nmol} \mathrm{l}^{-1}$, respectively. Hydrogenating $\mathrm{C} 13$ and $\mathrm{C} 14$ produced a slight change in $\left.{ }^{3} \mathrm{H}\right] \mathrm{PGF}_{2 \alpha}$ inhibition $\left(13,14\right.$-dihydro $\mathrm{PGF}_{2 \alpha^{\prime}} \mathrm{IC}_{50}=$ $\left.21 \pm 5 \mathrm{nmol} \mathrm{l}^{-1}\right)$. Dehydration at $\mathrm{C} 17$ and $\mathrm{C} 18\left(\mathrm{PGF}_{3 \alpha}\right)$ resulted in an $\mathrm{IC}_{50}$ value of $39 \pm 5 \mathrm{nmol} \mathrm{l}^{-1}$. Changes beyond $\mathrm{C} 16 \mathrm{had}$ little effect on binding $\left(\mathrm{PGF}_{3 \alpha^{\prime}}\right.$, fluprostenol, cloprostenol; $\mathrm{IC}_{50}$ $=39 \pm 5,34 \pm 6$ and $5 \pm 2 \mathrm{nmol}^{-1}$, respectively; Table 4).

\section{Discussion}

This study provides a pharmacological analysis of prostaglandin binding in the bovine corpus luteum. The systematic approach used in these experiments provided insight into the nature of prostaglandin binding in the corpus luteum.

It is apparent that $\mathrm{PGE}_{2}$ binds to both $\mathrm{FP}$ and $\mathrm{EP}$ receptors. This is indicated by the inhibition of $\left[{ }^{3} \mathrm{H}\right] \mathrm{PGF}_{2 \alpha}$ binding by $\mathrm{PGE}_{2}$ and, conversely, $\mathrm{PGF}_{2 \alpha}$ inhibition of $\left[{ }^{3} \mathrm{H}\right] \mathrm{PGE}_{2}$ binding. In addition, the flattened slopes for inhibition of $\left[{ }^{3} \mathrm{H}\right] \mathrm{PGE}_{2}$ by $\mathrm{PGD}_{2}, \mathrm{PGF}_{2 \alpha}$ and $\mathrm{PGE}_{1}$ indicated that there are two different binding sites with different affinities for $\left[{ }^{3} \mathrm{H}\right] \mathrm{PGE}_{2}$. This is also supported by the observation that the number of $\left[{ }^{3} \mathrm{H}\right] \mathrm{PGE}_{2}$ molecules $\left(2.9 \times 10^{10}\right)$ bound to the bovine luteal plasma membrane was higher than the number of $\left[{ }^{3} \mathrm{H}\right] \mathrm{PGE} \mathrm{E}_{1}$ $\left(1.6 \times 10^{10}\right)$ molecules bound. Therefore, studies in which $\mathrm{PGE}_{2}$ is used for either binding or physiological evaluations must be considered at least partially compromised because of this crossreactivity. For example, treatment of ovine large luteal cells with PGE $_{2}$ caused an increase in free intracellular calcium (Wiepz et al., 1993) with an $\mathrm{ED}_{50}$ value $\left(168 \mathrm{nmol} \mathrm{1}^{-1}\right.$ ) that corresponds closely to the affinity of the FP receptor for $\mathrm{PGE}_{2}$ observed in this study and in other investigations (Wiepz et al., 1992).

In contrast, $\mathrm{PGE}_{1}$ appeared to interact with only the EP receptor and not the FP receptor (this study; Rao, 1974; Kimball and Lauderdale, 1975; Wiepz et al., 1992). This was demonstrated by the large $\mathrm{IC}_{50}$ values for inhibition of $\left[{ }^{3} \mathrm{H}\right] \mathrm{PGD}_{2}$ or $\left[{ }^{3} \mathrm{H}\right] \mathrm{PGF}_{2 \alpha}$ by $\mathrm{PGE}_{1}$. Similarly, very high concentrations of $\mathrm{PGD}_{2}$ and $\mathrm{PGF}_{2 \alpha}$ were required to inhibit binding of $\left[{ }^{3} \mathrm{H}\right] P G E_{1}$. Several studies have demonstrated that $\mathrm{PGE}_{1}$ and $\mathrm{PGE}_{2}$ can have very different physiological effects on the corpus luteum. For example, in ewes in which the ovarian pedicle was treated with $\mathrm{PGF}_{2 \alpha^{\prime}}$ there was a decrease in luteal weight and serum progesterone concentration that could be restored to values observed in vehicle-treated ewes by simultaneous administration of $\mathrm{PGE}_{1}$ but not $\mathrm{PGE}_{2}$ (Reynolds et al., 1981). In addition, the luteal phase of ewes was extended by administration of $\mathrm{PGE}_{1}$ into the uterine horn ipsilateral but not contralateral to the corpus luteum (Huie et al., 1981). Likewise, administration of high doses of $\mathrm{PGE}_{1}$ in pseudopregnant rats delayed luteolysis, whereas administration of high doses of $\mathrm{PGE}_{2}$ accelerated the onset of luteolysis (Weems et al., 1979). Therefore, researchers interested in studying actions mediated through EP receptors in the corpus luteum should consider using $\mathrm{PGE}_{1}$ or other specific EP receptor agonists, rather than $\mathrm{PGE}_{2}$ because of the interaction of $\mathrm{PGE}_{2}$ with $\mathrm{FP}$ as well as EP 
Table 3. Prostaglandin $\mathrm{E}_{1}$ agonists, structure, inhibition constants and specificity

\begin{tabular}{|c|c|c|c|}
\hline Prostaglandin & Chemical structure & $\mathrm{IC}_{50}\left(\mathrm{nmol} \mathrm{l}^{-1}\right)$ & Specificity \\
\hline $\mathrm{PGE}_{1}$ & & 14 & - \\
\hline M\&B 28,767 & & 3 & $\mathrm{EP}_{3}{ }^{\mathrm{a}}$ \\
\hline $\mathrm{PGE}_{2}$ & & 8 & - \\
\hline 11-deoxy $\mathrm{PGE}_{1}$ & & 8 & $\mathrm{EP}_{2}>\mathrm{EP}_{3}^{\mathrm{bc}}$ \\
\hline 16,16-dimethyl PGE & & 9 & $\mathrm{EP}_{3}>\mathrm{EP}_{1}>\mathrm{EP}_{2}^{\text {ed }}$ \\
\hline 17-phenyl trinor $\mathrm{PGE}_{2}$ & & 17 & $\mathrm{EP}_{1}>\mathrm{EP}_{3}^{\mathrm{e}}$ \\
\hline Sulprostone & & 23 & $\mathrm{EP}_{3}>\mathrm{EP}_{1}^{\mathrm{fg}}$ \\
\hline Misoprostol & & 82 & $\mathrm{EP}_{2}>\mathrm{EP}_{3}{ }^{\mathrm{gh}}$ \\
\hline SC-19220 & & $>10000$ & $E P_{1}$ \\
\hline
\end{tabular}

Arrows indicate the sites at which the analogues differ from $\mathrm{PGE}_{1}$.

Superscripts indicate references that identify EP receptor specificity: 'Negishi et al., 1993; 'Regan et al., 1994; 'Li et al., 1993; dJumblatt and Paterson, 1991; 'Coleman et al., 1994; 'Watabe et al., 1993; '"Yang et al., 1994; 'hHonda et al., 1993; 'Coleman et al., 1985. 
Table 4. Prostaglandin $\mathrm{F}_{2 \alpha}$ analogues, structure and inhibition constants

\begin{tabular}{|c|c|c|c|}
\hline Prostaglandin & Chemical structure & $\mathrm{IC}_{50}\left(\mathrm{nmol} \mathrm{l}^{-1}\right)$ & Differs from $\mathrm{PGF}_{2 \alpha}$ at \\
\hline $\mathrm{PGF}_{2 \pi}$ & & 10 & - \\
\hline PGF $_{2 \alpha}$ dimethyl amide & & $>10000$ & $\mathrm{C} 1$ \\
\hline $\mathrm{PGF}_{2 \alpha}$ isopropyl ester & & 383 & $\mathrm{C} 1$ \\
\hline 5-trans $\mathrm{PGF}_{2 \alpha}$ & & 61 & $\mathrm{C} 5 / \mathrm{C} 6$ bond \\
\hline $\mathrm{PGF}_{1 \alpha}$ & & 153 & C5/C6 bond \\
\hline $\mathrm{PGE}_{2}$ & & 157 & $\mathrm{C} 9$ \\
\hline $\mathrm{PGD}_{2}$ & & 27 & $\mathrm{C} 11$ \\
\hline 11-deoxy PGF PG $_{2 \alpha}$ & & 37 & C11 \\
\hline 13,14 -dihydro $\mathrm{PGF}_{2 \alpha}$ & & 21 & $\mathrm{C} 13 / \mathrm{C} 14$ bond \\
\hline 15-keto $\mathrm{PGF}_{2 \alpha}$ & & 667 & $\mathrm{C} 15$ \\
\hline $\mathrm{PGF}_{3 \alpha}$ & & 39 & $\mathrm{C} 17 / \mathrm{C} 18$ bond \\
\hline Fluprostenol & & 34 & $\mathrm{C} 17$ tail \\
\hline Cloprostenol & & 5 & C17 tail \\
\hline
\end{tabular}

Arrows indicate the sites at which the analogues differ from $\mathrm{PGF}_{2 \alpha^{\circ}}$ 
receptors. This may be less of a problem in tissues that contain small numbers of FP receptors (Tsai et al., 1998). The obvious problem with using $\mathrm{PGE}_{1}$ is that $\mathrm{PGE}_{2}$ appears to be the physiological ligand for EP receptors in most cases. For example, the uterine concentrations of $\mathrm{PGE}_{2}$ are approximately tenfold greater than those of $\mathrm{PGE}_{1}$ (Wilson et al., 1972). Thus, it is unclear whether crossreactivity of $\mathrm{PGE}_{2}$ with the FP receptor is involved in normal physiological events or is a pharmacological phenomenon.

Although $\mathrm{PGD}_{2}$ binds with high affinity to luteal plasma membrane, it is likely that $\mathrm{PGD}_{2}$ is binding to the FP receptor rather than a specific DP receptor. In preliminary experiments, a specific agonist for the DP receptor (BW$245 \mathrm{C})$ was unable to displace either $\left[{ }^{3} \mathrm{H}\right] \mathrm{PGD}_{2}$ or $\left[{ }^{3} \mathrm{H}\right] \mathrm{PGF}_{2 \alpha}$ binding in bovine luteal plasma membrane $\left(\mathrm{IC}_{50}>10 \mu \mathrm{mol}\right.$ $\mathrm{l}^{-1}$; L. E. Anderson and M. C. Wiltbank, unpublished). Wiepz et al. (1992) reported that $\mathrm{PGD}_{2}$ inhibits $\left[{ }^{3} \mathrm{H}\right] \mathrm{PGF}_{2 \alpha}$ binding in the ovine corpus luteum. Binding studies in mammalian COS cells transfected with human FP receptor also demonstrated that $\mathrm{PGD}_{2}$ inhibits binding of $\left[{ }^{3} \mathrm{H}\right] \mathrm{PGF}_{2 \alpha}$ (Abramovitz et al., 1994). Cloning and expression of the bovine FP receptor also showed crossreactivity with $\mathrm{PGD}_{2}$ (Sakamoto et al., 1994). Higher concentrations of $\mathrm{PGD}_{2}$ were required to displace $\left[{ }^{3} \mathrm{H}\right] \mathrm{PGF}_{2 \alpha}$ binding to mouse and rat FP receptors (Lake et al., 1994; Sugimoto et al., 1994), indicating a species difference in receptor crossreactivity. Interestingly, the DP receptor does not appear to bind either $\mathrm{PGE}_{2}$ or $\mathrm{PGF}_{2 \alpha}$ in mice or humans (Hirata et al., 1994; Boie et al., 1995).

Experiment 2 was designed to determine the subtype of luteal EP receptor using pharmacological agonists. The finding that M\&B 28,767 displaced $\left[{ }^{3} \mathrm{H}\right] \mathrm{PGE}_{1}$ with high affinity implies that an $\mathrm{EP}_{3}$ type receptor is present (Negishi et al., 1993). In addition, 16,16-dimethyl $\mathrm{PGE}_{2}$ preferentially binds $\mathrm{EP}_{3}$ receptors, although this compound may have nonselective binding to all EP receptors in some species (Jumblatt and Paterson, 1991; Li et al., 1993). Furthermore, high affinity binding of sulprostone indicates that most luteal prostaglandin $\mathrm{E}$ binding is due to $\mathrm{EP}_{3}$ receptors (Watabe et al., 1993; Yang et al., 1994). The $\mathrm{EP}_{2}$ receptor agonists available crossreact with the $\mathrm{EP}_{3}$ receptor, thus the presence of an $\mathrm{EP}_{2}$ receptor could not be confirmed. The high affinity binding of 11-deoxy PGE (Regan et al., 1994) indicates that an $\mathrm{EP}_{2}$ receptor may be present. However, misoprostol bound with lower affinity, as may be expected for an $\mathrm{EP}_{3}$ receptor. Although several $\mathrm{EP}$ receptor agonists bind to the $\mathrm{EP}_{1}$ receptor, most of these also bind to $\mathrm{EP}_{3}$ receptors. The lack of binding of the $\mathrm{EP}_{1}$ selective agonist $\mathrm{SC}$ 19220 (Coleman et al., 1985) indicates that $\mathrm{EP}_{1}$ receptors may not be present in the bovine corpus luteum, although low solubility of this compound may cause aberrant results. The slope of the inhibition curves indicated that the affinity of only one receptor was being inhibited by each of the agonists. Thus, these results are consistent with the luteal prostaglandin $\mathrm{E}$ receptor being of the $\mathrm{EP}_{3}$ receptor subtype. An $\mathrm{EP}_{2}$ receptor may also be present, but could not be demonstrated directly. Further studies with EP receptorspecific antibodies would provide more direct evidence for these conclusions.

Experiment 3 provided insight into the moieties involved in $\mathrm{PGF}_{2 \alpha}$ binding. The C9 position was the only moiety that altered $\mathrm{PGF}_{2 \alpha}$ binding, and was unique to the $\mathrm{PGF}_{2 \alpha}$ molecule compared with the other common prostaglandins. Changing the $\mathrm{C} 9$ from hydroxyl to ketone $\left(\mathrm{PGF}_{2 \alpha}\right.$ to $\left.\mathrm{PGE}_{2}\right)$ increased the $\mathrm{IC}_{50}$ value by more than tenfold. In contrast, alteration of the other unique site for $\mathrm{PGF}_{2 \alpha^{\prime}}, \mathrm{C} 11$, had a minimal effect on $\mathrm{PGF}_{2 \alpha}$ binding. This could be demonstrated by changing the C11 site to a ketone $\left(\mathrm{PGD}_{2}\right)$ or by complete removal of the hydroxyl group (11-deoxy $\mathrm{PGF}_{2 \alpha}$ ). Interestingly, removal of the C11 hydroxyl from the $\mathrm{PGE}_{2}$ molecule also had little effect on $\mathrm{PGE}_{1}$ binding. Thus, it appears that $\mathrm{C} 9$ offers the primary site for luteal prostaglandin receptor specificity, whereas C11 moieties appear to have minimal effect on bovine luteal EP or FP receptor binding.

The three groups that were important for $\mathrm{PGF}_{2 \alpha}$ binding but were not specific to the $\mathrm{PGF}_{2 \alpha}$ molecule were $\mathrm{C} 1, \mathrm{C} 5 / \mathrm{C} 6$, and C15. Replacement of the $\mathrm{C} 1$ carboxylic acid with large groups (dimethyl amide or isopropyl ester) almost eliminated binding to the receptor. Unfortunately, there were no compounds available that altered only the nature of the carboxylic acid without the addition of large residues. It has been proposed that the $\mathrm{C} 1$ carboxylic acid forms a Schiff base with conserved arginine in the seventh transmembrane domain (residue 291 of the bovine FP receptor; Sakamoto et al., 1994) and stabilizes binding of all prostaglandins to their receptors.

The C5/C6 double bond is important for $\mathrm{PGF}_{2 \alpha}$ binding, as indicated by the finding that removal of this double bond $\left(P G F_{1 \alpha}\right)$ increased the $\mathrm{IC}_{50}$ value by more than tenfold, and isomerization of the bond from cis to trans conformation (5trans $\mathrm{PGF}_{2 \alpha}$ ) significantly increased the $\mathrm{IC}_{50}$ value. Although this bond is not unique to the $\mathrm{PGF}_{2 \alpha}$ molecule, it appears to have a major impact on receptor specificity. This is demonstrated by the fact that PGE (C5/C6 double bond intact) has a moderate $\mathrm{IC}_{50}$ value $\left(157 \mathrm{nmol} \mathrm{l}^{-1}\right)$, whereas $\mathrm{PGE}_{1}$ (C5/C6 double bond removed) caused virtually no displacement of $[3 \mathrm{H}] \mathrm{PGF}_{2 \alpha}\left(>10000 \mathrm{nmol} \mathrm{l}^{-1}\right)$. The $\mathrm{C} 5 / \mathrm{C} 6$ double bond did not alter luteal prostaglandin $\mathrm{E}$ binding, as shown by high affinity binding of $\mathrm{PGE}_{1}$ or $\mathrm{PGE}_{2}$ as well as a number of different agonists that contained (sulprostone, 16,16-dimethyl $\mathrm{PGE}_{2}$, 17-phenyl trinor $\mathrm{PGE}_{2}$ ) or did not contain (M\&B 28,767, 11-deoxy $\mathrm{PGE}_{1}$ ) the C5/C6 double bond.

The hydroxyl in the C15 position appears to be essential for binding because changing this group to a ketone (15-keto $\mathrm{PGF}_{2 \alpha}$ ) markedly reduced affinity for the FP receptor. It is possible that the hydroxyl in the $\mathrm{C} 15$ position, along with the carboxylic acid at $\mathrm{C} 1$, provide ionic interactions that stabilize $\mathrm{PGF}_{2 \alpha}$ binding to the FP receptor. There was little effect on $\mathrm{PGF}_{2 \alpha}$ or prostaglandin $\mathrm{E}$ binding or activity when alterations were made in the molecule beyond $\mathrm{C} 17$, similar to the findings of other studies (Negishi et al., 1993; Watabe et al., 1993; Yang et al., 1994; Graves et al., 1995). The addition of larger groups, such as phenols, after C17 has been used to increase the half-life for prostaglandins in vivo since these compounds are less susceptible to 15-hydroxy prostaglandin dehydrogenase (Miller et al., 1975; Granström, 1975). Phenylsubstituted PGF $2 \alpha$ is at least as potent as PGF ${ }_{2 \alpha}$ (Miller et al., 1975; Resul et al., 1993).

In summary, high affinity binding of prostaglandins to 
bovine luteal plasma membrane indicated the presence of specific FP and EP receptors. The affinity of different prostaglandins and prostaglandin analogues for these receptors indicated moieties on the prostaglandin molecule that are essential for binding to luteal prostaglandin receptors and that luteal EP receptor is probably of the $\mathrm{EP}_{3}$ subtype, although results on the presence of luteal $\mathrm{EP}_{2}$ receptors are equivocal. The group attached to the $\mathrm{C} 9$ position appears to be most critical for determining specificity of luteal FP and EP receptors. A cis double bond at C5/C6 is also critical for luteal FP but not EP receptor binding. Other parts of the prostaglandin molecule, including C11, appear to be minimally important for determination of luteal prostaglandin receptor specificity.

The authors are grateful to Joy Pate and Leslie Jones for performing the $\mathrm{PGF}_{2 \alpha}$ radioimmunoassay and to Steve Tomasko for technical assistance. This study was supported by NIH grant HD-32623.

\section{References}

Abramovitz M, Boie $Y$, Nguyen T, Rushmore TH, Bayne MA, Metters KM, Slipetz DM and Grygorczyk R (1994) Cloning and expression of a cDNA for the human prostanoid FP receptor Journal of Biological Chemistry 269 $2632-2636$

Boie Y, Sawyer N, Slipetz DM, Metters KM and Abramovitz M (1995) Molecular cloning and characterization of the human prostanoid DP receptor Journal of Biological Chemistry 270 18 910-18916

Coleman RA, Kennedy $\mathbf{L}$ and Sheldrick RLG (1985) AH6809, a prostanoid EP1 receptor blocking drug British Journal of Pharmacology 85 273P

Coleman RA, Smith WL and Narumiya S (1994) VIII. International union of pharmacology classification of prostanoid receptors: properties, distribution, and structure of the receptors and their subtypes Pharmacological Reviezs $\mathbf{4 6}$ 205-229

Coleman RA, Eglen RM, Jones RL et al. (1995) Prostanoid and leukotriene receptors: a progress report from the IUPHAR working parties on classification and nomenclature Advances in Prostaglandin, Thromboxane and Leukotriene Research 23 283-285

Gimenez T and Henricks DM (1983) Prolongation of the luteal phase by $\mathrm{PGE}_{2}$ during the estrous cycle in the cow. A preliminary report Theriogenology 19 693-700

Granström E (1975) Metabolism of 17-phenyl-18,19,20-trinor $\mathrm{PGF}_{2 \alpha}$ in the cynomolgus monkey and the human female Prostaglandins $919-45$

Graves PE, Pierce KL, Bailey TJ, Rueda BR, Gil DW, Woodward DF, Yool AJ, Hoyer PB and Regan JW (1995) Cloning of a receptor for $\mathrm{PGF}_{21}$ from the ovine corpus luteum Endocrinology 136 3430-3436

Hirata M, Kakizuka A, Aizawa M, Ushikubi F and Narumiya S (1994) Molecular characterization of a mouse prostaglandin $D$ receptor and functional expression of the cloned gene Proceedings National Academy of Sciences USA 9111 192-11 196

Houda A, Sugimoto $Y$, Namba T, Watabe A, Irie A, Negishi M, Narumiya S and Ichikawa A (1993) Cloning and expression of a cDNA for mouse prostaglandin E receptor EP2 subtype Journal of Biological Chemistry 268 7759-7762

Huie JM, Magness RR, Reynolds LP, Hoyer G, Huecksteadt, Colcord M, Stalcup B, Whysong GL and Weems CW (1981) Effect of chronic ipsilateral or contralateral intrauterine infusion of $\mathrm{PGE}_{1}$ on luteal function of unilaterally ovariectomized ewes Prostaglandins 21 945-955

Jumblatt $M$ and Paterson CA (1991) Prostaglandin $E_{2}$ effects on corneal endothelial cyclic adenosine monophosphate synthesis and cell shape are mediated by a receptor of the $\mathrm{EP}_{2}$ subtype Investigative Opthalmology and Visual Science 32 360-365
Kimball FA and Lauderdale JW (1975) Prostaglandin $E_{1}$ and $F_{2 a}$ specific binding in bovine corpora lutea: comparison with luteolytic effects Prostaglandins 10 313-331

Knickerbocker JJ, Wiltbank MC and Niswender GD (1988) Mechanisms of luteolysis in domestic livestock Domestic Animai Endocrinology 591-107

Lake S, Gullberg H, Wahlqvist J, Sjogren A-M, Kinhult A, Lind P, Hellstrom-Lindahl E and Stjernschhantz J (1994) Cloning of the rat and human prostaglandin $F_{2 x}$ receptors and the expression of the rat prostaglandin $\mathrm{F}_{2 \alpha}$ receptor Federation of European Biochemical Societies 335 317-325

Li D-Y, Varma RD, Chatterjee PT, Fernandez H, Abran D and Chemtob $S$ (1993) Fewer $\mathrm{PGE}_{2}$ and $\mathrm{PGF}_{2 \alpha}$ receptors in brain synaptosomes of newborn than of adult pigs Journal of Pharmacology and Experimental Therapeutics 267 1292-1297

Miller WL, Weeks JR, Lauderdale JW and Kirton KT (1975) Biological activities of 17-phenyl-18,19,20-trinor prostaglandins Prostaglandins 9 9-18

Negishi $M$, Namba T, Sugimoto $Y$, Irie $A$, Katada $T$, Narumiya $S$ and Ichikawa $\mathbf{A}$ (1993) Opposite coupling of prostaglandin $E$ receptor $\mathrm{EP}_{3 \mathrm{c}}$ with Gs and Go Journal of Biological Chemistry $26826067-26070$

Negishi M, Sugimoto $Y$ and Ichikawa A (1995) Molecular mechanisms of diverse actions of prostanoid receptors Biochimica et Biophysica Acta 1259 $109-120$

Rao CV (1974) Characterization of prostaglandin receptors in the bovine corpus luteum cell membranes Journal of Biological Chemistry 249 7203-7209

Regan JW, Bailey TJ, Pepperl DJ et al. (1994) Cloning of a novel human prostaglandin receptor with characteristics of the pharmacologically defined EP ${ }_{2}$ subtype Molecular Pharmacology 46 213-220

Resul B, Stjernschantz J, No K, Liljebris C, Selén G, Astin M, Karlsson M and Bito LZ (1993) Phenyl-substituted prostaglandins: potent and selective antiglaucoma agents Journal of Medical Chemistry 36 243-248

Reynolds LP, Stigler J, Hoyer GL, Magness RR, Huie JM, Huecksteadt TP, Shysong GL, Behrman HR and Weems CW (1981) Effect of PGE 1 or PGE on $\mathrm{PGF}_{2 \alpha}$-induced luteolysis in nonbred ewes Prostaglandins 21 957-972

Sakamoto K, Ezashi T, Miwa K, Okuda-Ashitaka E, Houtani T, Sugimot T, Ito $S$ and Hayaishi $O$ (1994) Molecular cloning and expression of a cDNA of the bovine PGF $_{2 \alpha}$ receptor Journal of Biological Chemistry 2693881-3886

Scatchard G (1949) The attraction of proteins for small molecules and ions Annals of the New York Academy of Science 51 660-672

Sugimoto $Y$, Hasumoto $K$, Namba T, Irie A, Katsuyama M, Negishi M, Kakizuka A, Narumiya S and Ichikawa A (1994) Cloning and expression of a cDNA for mouse prostaglandin F receptor Journal of the American Society for Biochemistry and Molecular Biology 269 1356-1360

Townson DH and Pate JL (1994) Regulation of prostaglandin synthesis by interleukin-1 $\beta$ in cultured bovine luteal cells Biology of Reproduction $\mathbf{5 1}$ $480-485$

Tsai S-J, Anderson LE, Juengel J, Niswender GD and Wiltbank MC (1998) Regulation by $\mathrm{PGF}_{2 \alpha}$ of $\mathrm{FP}$ and $\mathrm{EP}_{3}$ receptor mRNA in the ovine corpus luteum Journal of Reproduction and Fertility 114 69-75

Ushikubi F, Hirata M and Narumiya S (1995) Molecular biology of prostanoid receptors: an overview Journal of Lipid Mediators and Cell Signaling 12 343-359

Watabe A, Sugimoto $Y$, Honda A, Irie A, Namba T, Negishi M, Ito S, Narumiya $S$ and Ichikawa A (1993) Cloning and expression of cDNA for a mouse EP, subtype of PGE receptor Journal of Biological Chemistry 26820 175-20178

Weems CW, Huecksteadt TP, SJahli $\mathbf{H}$ and Lavelle $\mathbf{P}$ (1979) Effects of $\mathrm{PGE}_{1}$ or $\mathrm{PGF}_{2 \alpha}$ on luteal function in pseudopregnant rats Prostaglandins $17891-901$

Wiepz GJ, Wiltbank MC, Nett TM, Niswender GD and Sawyer HR (1992) Receptors for prostaglandins $\mathrm{F}_{2 a}$ and $\mathrm{E}_{2}$ in ovine corpora lutea during maternal recognition of pregnancy Biology of Reproduction 47 984-991

Wiepz GJ, Wiltbank MC, Kater SB, Niswender GD and Sawyer HR (1993) $P E_{2}$ attenuates $\mathrm{PGF}_{20}$-induced increases in free intracellular calcium in ovine large luteal cells Prostaglandins 45 167-176

Wilson L, Jr, Cenedella R, Butcher R and Inskeep E (1972) Levels of prostaglandins in the uterine endometrium during the ovine estrous cycle Journal of Animal Science 34 93-99

Yang J, Xia M, Goetzl E and An S (1994) Cloning and expression of the $\mathrm{EP}_{3}-$ subtype of human receptors for $\mathrm{PGE}_{2}$ Biochemical and Biophysical Research Communications 198 999-1006 